\title{
ON INTELLECTUS AGENS AND ARISTOTELIAN SEPARATE SUBSTANCES: AQUINAS' WATERLOO ${ }^{1}$
}

Hector Zagal*

RESUMO Este artigo trata do comentário de São Tomás de Aquino ao De Anima III de Aristóteles, no qual se encontra a famosa analogia da luz. Sustenta-se que, devido às limitações da analogia, São Tomás é forçado a introduzir uma série de elementos neoplatônicos incompatíveis com a filosofia de Aristóteles. $O$ intuito do autor é explicar essa "traição" à filosofia de Aristóteles, feita por um de seus comentadores mais abalizados. Conclui-se que, a fim de conciliar o mundo pagão com a teologia católica, Tomás de Aquino precisa redirecionar Aristóteles, através de uma argumentação menos econômica; isto é, através da introdução do Intellectus Agens.

Palavras-chave Mente, Filosofia Medieval, Intelecto, Alma, Conhecimento

ABSTRACT The present paper deals with Saint Thomas's commentary to Aristotle's De Anima III, in wich we find the famous analogy of light. It is sustained that due to the limitations of the analogy, Saint Thomas is forced to introduce a series of Neo-platonic elements incompatible with Aristotle's philosophy. The author means to explain this "betrayal" to Aristotle's philosophy by one of his most credited commentators. It is concluded that in order to reconcile the pagan world with the Catholic theology, Thomas Aquinas

* Professor da Facultad de Filosofia da Universidad Panamerica, Mexico City. Artigo recebido em abril de 2004 e aprovado em abril de 2005. hzagal@mx.up.mx.

1 I sincerely thank Alberto Amézquita (Universidad Panamericana) and José Luis Rivera (The Catholic University of America) for their valuable comments and suggestions in the writing of this paper.

KRITERION, Belo Horizonte, no 111, Jun/2005, p. 117-137 
needs to redirect Aristotle through a less economical argument; that is, the introduction of the Intellectus Agens.

Keywords Mind, Medieval Philosophy, Intellect, Soul, Knowledge

\begin{abstract}
Virtutes naturales corporum naturalium consequuntur eorum formas substantiales, quas sortiuntur ex impressione caelestium corporum: et ideo ex eorundem impressione sortiuntur quasdam virtutes activas.
\end{abstract}

S.Th. II-II, q. 96, a. 2 ad $2^{2}$

\title{
Introduction
}

Aristotle draws the celebrated analogy between the Intellectus Agens and light in De Anima III, 5, and Aquinas develops this idea in his commentary to this passage. I don't mean to explain here Aristotle's text, but to evaluate Saint Thomas's commentary. I will outline the limitations of this analogy, and the difficulties found by Thomas in trying to explain it. In my view, Aquinas introduced a Neoplatonic element in his commentary which is incompatible with Aristotle's position. To prove my point, I shall discuss briefly the optical theories of Aristotle and Saint Thomas; then I will discuss what it means to say that the Intellectus Agens is an act; finally, I will show why Aquinas thought that the nature of the Intellectus Agens required an appeal to separate substances. My conclusion is that the recourse to participation is not genuinely Aristotelian, but Saint Thomas was forced to introduce it to avoid the deification of the Intellectus Agens. I'll concentrate my efforts around some paragraphs from the Sententiae super De Anima, with some references to works such as the Quaestiones disputatae de anima, Summa Contra Gentiles, Summa Theologiae, De unitate intellectus contra Averroistas and De substantiis separatis ad fratrem Reginaldum.

\section{De Anima III, 5, 430 10-25 and Averroism}

The complexities of this chapter are well known, and scholars of all ages have tried to tame them. Alexander introduced in his commentary a series of very influential distinctions regarding the nature of the intellect, and Averroes

2 "As forças naturais dos corpos naturais seguem as formas substanciais destes, as quais são obtidas pela influência dos corpos celestes: como conseqüência, pela influência dos corpos celestes, os corpos naturais obtêm certas forças ativas." 
expanded these amendments into a fully developed theory. The Intellectus Possibilis is explained as some kind of separate substance which is capable of knowledge. This Intellectus is physically separated from everything material. It is numerically one for all humankind, and immortal.

According to Averroes, human knowledge consists in the union of the vis cogitativa of the human being with the Intellectus Possibilis by way of the Intellectus Agens, which illuminates the phantasmata of our imagination. Although Averroes' opinion on this topic is highly debatable, it is not of our primary interest here. Our concern is that it influenced - rightly or wrongly interpreted - Saint Thomas' views.

The Averroist interpretation became a fundamental source of inspiration for Parisian Masters of Philosophy in the 13th century. It has been widely debated as to whether the Latin Averroists really understood Averroes. ${ }^{3}$ In any case, his influence worried the religious authorities of the time. In 1270, Stephen Tempier, bishop of Paris, condemned thirteen theses allegedly held by professors of the Arts Faculty at Paris. Those propositions, Tempier believed, contained the essence of Latin Averroism. The propositions more closely related to the commentary on De Anima 430a 10-25 are the following:

a) The intellect of all men is individual and numerically one.

b) It is false and improper to say that "Man understands".

c) The soul, the form of man qua man, is corrupted with the corruption of the body.

d) The separated soul, after death, does not suffer bodily fire.

e) Everything happening in the sublunar world is governed by the necessity of the celestial bodies.

The last proposition is usually omitted when discussing Latin Averroism, but it is important to understand why Saint Thomas was suspect of heresy. His commentary to De Anima III, 5, tries to refute the arguments of Alexander and Averroes, but it leaves - so to speak — some loose wires dangling dangerously in the air.

\section{Saint Thomas's argument against the Averroist interpretation}

Aquinas believed that the Intellectus Agens is, properly speaking, a power of the individual human being. He supports this affirmation by two arguments.

I. In St Thomas' mind, Aristotle applies the term "separate" to the Intellectus

3 Ralph Mclnerny discusses this point in Aquinas against the averroist (West Lafayette: Purdue University Press, 1993). 
Agens to indicate a spiritual power. The Intellectus is separate because it lacks a bodily organ.

If we compare this remark with In De Anima III, lectio X, it seems that Aquinas is here guilty of a petitio principii. The Greek text says horistós; whatever you make of that word is an interpretation. ${ }^{4}$ Nevertheless, Aquinas' sententia seems plausible: heavenly bodies are separate substances quodammodo, and mathematical objects may be called "separate" too. In fact, Aristotle uses the adjective horistós in many different senses.

II. The truly important argument can be outlined in a very simple way.

a) Every natural being has the capacity to exercise its natural faculties.

b) To know is a faculty of the human being.

c) The intervention of the Intellectus Agens is necessary for intellectual human knowledge.

d) Ergo, the Intellectus Agens is a formal principle of the human being.

Saint Thomas is explicit on this point: the Intellectus Agens is a power of the soul, and therefore, it belongs formaliter to the human being. From hereon I will call this argument the "Complete Nature Argument" (CNA).

The genuinely Aristotelian descent of the argument cannot be denied: Nature does nothing in vain; therefore, human beings must possess all the relevant powers in order to act according to their nature. For now there's nothing to object here. The difficulty, however, is that the conclusion (d) goes somewhat beyond the premises: (d) does not follow from the premises; the conclusion should be rather:

(4) Ergo, the Intellectus Agens is necessary for natural human knowledge.

The fallacy lies in the identification of a formal principle with a natural principle. ${ }^{5}$ According to Aquinas, if the Intellectus Agens does not exist formaliter in the human being, the human being does not know naturally. The weakness of this argument is obvious if we compare the Intellectus Agens with light, as Aristotle himself does. Let's see, then, how light works. The argument may go as follows:

a) Physical light is a necessary condition for the eye to see colors.

b) The human being needs light to see.

From these premises Saint Thomas does not conclude:

4 See CASTON, Victor. Aristotle two Intellects: a modest proposal. Phronesis, XLIV-3, p. 207-208, 1999; and RIST, John M. Notes on Aristotle De Anima 3.5. Classical Philology, 61, p. 8-20, 1966.

5 For a better understanding of this relationship see AQUINAS. De principiis naturae, chap. I. 
c) Natural light is a power of the human being. but rather, correctly,

d) Natural light is a necessary condition for sight.

I will call this argument the "Natural Light Argument" (NLA).

To support my claim, I emphasize that this process cannot be artificial just because the efficient cause of an event is external. Aristotle often uses a similar example: the influence of the sun in the sublunar world is natural and necessary, for the generation and corruption of plants and animals on this Earth depend necessarily on the influence of the sun, an agent external to the Earth itself. The intervention of an external agent does not turn a natural phenomenon into an artificial one. In the Natural Light Argument, again, Nature does nothing in vain: there is generation and corruption naturally on the surface of the Earth, but with the aid of an agent from the supralunar world, namely, the Sun. Could we conclude then that the Intellectus Agens may be another natural external agent, like the sun?

\section{Can the Intellectus Agens be an external agent?}

Is the Intellectus Agens an external source of light, like the sun? Saint Thomas rejects this possibility in lectio X. The vis intellectiva is not external to the human being, as Averroes' wrote in the Comentarium magnum. Aquinas writes:

Nor is it enough to say that the intelligible notions formed by the Intellectus Agens subsist somehow in the phantasmata, which are certainly intrinsic to us; for as we have already observed in treating the Intellectus Possibilis, objects only become actually intelligible when abstracted from phantasmata; so that merely by way of the phantasmata, we cannot attribute the work of the Intellectus Agens to ourselves. ${ }^{6}$

The quid of the objection seems to anticipate the rationalistic problem of the communication of the substances, although, in fact, it is just the Complete Nature Argument at work. If the vis intellectiva of the human being is external, then we cannot say that the human being knows by its own powers, and therefore, we cannot say properly that "the human being knows." The presence of the phantasmata in the mind does not guarantee the humanity of the act of

6 I quote from In De Anima III, lectioX, § 735, translated by Kenelm Foster and Silvester Humphrie's Commentary on Aristotle's De Anima. (Notre Dame: Dumb Ox Books, 1994); for the Latin edition, see Angeli M. Pirotta, Sancti Thomaes Aquinatis in Aristotelis libros De Anima Commentarium (Rome: Marietti, 1959). 
intellection, for the decisive factor is that the principle of action is internal to the agent. ${ }^{7}$ This way, if the phantasmata are actualized as intelligible species by the intervention of the Intellectus Agens, then the vis intellectiva must be internal. The Intellectus Agens is not — according to Saint Thomas - a "ghost in the machine": it is a power of the living human being.

The problem now is to determine what Aquinas meant by saying that the Intellectus Agens is a power intrinsic to the human being. The easiest solution is to say that the Intellectus Agens is just another power of the human being. Unfortunately, Saint Thomas introduces the talk of separate substances into this process and, by doing so, he spoils his own explanation.

\section{The ace in the hole: Aristotelian light}

I made an observation above about the natural light argument (NLA), which will prove to raise quite serious problems. Indeed, Aristotle himself introduces these problems by drawing the Analogy of Light (AL) as a device to explain the work of the Active Intellect:

"And in fact thought, as we have described it, is what it is by virtue of becoming all things, while there is another which is what it is by virtue of making all things: this is a sort of positive state like light; for in a sense light makes potential colors into actual colors". ${ }^{8}$

Aristotle sought to explain the work of the Intellectus Agens with the analogy:

$$
\text { Light color }
$$

\section{Intellectus Agens phantasmata}

We have seen above that this example may be construed as to say that light is an external agent, and this is the key to my objection. My objection against the analogy of the Active Intellect with light is based on the Natural Light Argument. Light is an external agent that makes colors visible, or from a modern perspective, we might say that color is the reflection of light on bodies. In the NLA, premise (1) affirms that physical light is a necessary condition to see colors. I have chosen the expression "necessary condition" and not "cause"

7 See In De Anima III, lectio X (Rome: Marietti, 1959), § 731.

8 De Anima III, 5, 430 a 14-17. 
because, according to Aristotelian optics, colors are themselves visible; light only makes the medium visible. ${ }^{9}$ In other words, in Aristotelian optics it is difficult to determine to what extent light can be considered as an external efficient cause of the visibility of colors.

Saint Thomas seems to be aware of the limits of the analogy, for he comments:

"So he [Aristotle] calls it a state, and compares it to light which quodammodo brings colors from potency to act; - quodammodo, because, as we have seen, color is visible of itself; all that light does is to actualize a transparent medium which can then be modified by color so that color is seen" ${ }^{10}$

The problem then is see whether this quodammodo really makes the fix the analogy, so that from the Natural Light Argument we can jump to the Complete Nature Argument. In the Quaestiones disputatae de anima, Saint Thomas takes some time to deal with this difficulty.

Ad Quartum dicendum quod de lumine, ut Commentator dicit in II De Anima, est duplex opinio. Quidam enim dixerunt quod lumen necessarium est ad videndum, quantum ad hoc quod dat virtutem coloribus, ut possint movere visum; quasi color non ex seipso sit visibilis, sed per lumen. Sed hoc videtur Aristoteles removere, cum dicit in II De Anima, quod color est per se visibilis; quod non esset, si solem ex lumine haberet visibilitatem. [...] Comparatio ergo luminis ad intellectum agentem non est quantum ad omnia; cum intellectus agens ad hoc sit necessarius ut faciat intelligibilia in potentia esse intelliggibilia actu. ${ }^{11}$

\section{While commenting De Anima II, 4 Saint Thomas writes:}

Whatever is visible is color and color is what lies upon what is in itself visible; "in itself" here means not that visibility is involved in the definition of what thus underlies color, but that that substratum contains in itself the cause of visibility. Every color has in it the power to set in movement what is actually transparent; that power constitutes its very nature. That is why it is not visible except with the help of light; it is only in light that the color of a thing is seen. ${ }^{12}$

9 See De sensu II, 437 $17 \mathrm{ff}$ and II, 438b $4 \mathrm{ff}$.

10 In De Anima III, lectio X (Rome: Marietti, 1959), § 730.

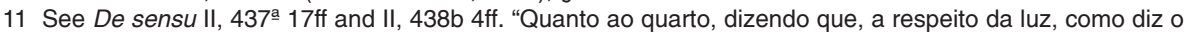
comentador em De Anima II, a opinião é dividida. Alguns disseram que a luz é necessária à visão, pois dá força às cores, para que possam provocar a vista; como se a cor não fosse, por si só, vísivel, mas através da luz. Mas parece que Aristóteles afasta esse argumento quando diz em De Anima /l que a cor é visível por si; [...] Portanto, a comparação entre luz e intelecto não é medida para tudo; visto que, para isso, o intelecto agente seja necessário para que faça as coisas inteligíveis em potência serem inteligíveis em ato."

12 De Anima II, 7, 418a 30ff. 
So, according to Aquinas, we can develop the following argument:

a) Color is in itself visible.

b) Color does not act at a distance, i.e., it effects sight through a medium (the transparent).

c) Color moves the transparent, i.e., color actualizes the visibility of the transparent.

d) Light is also necessary, so that the transparent medium "transports" the color to the eye.

e) Ergo, light is not per se cause of the visibility of color.

f) Ergo, we cannot see color without light, but color is per se visible.

g) Ergo, if there is light, there is color, while it is not necessary that, if there is color, there is light.

If we try to apply the conclusions of this argument to explain the proposition "Intellectus Agens est quodammodo lux"13 we can see that the analogy between the intellectus agens and light is not as simple as it seems. In my opinion, to say that the "intellect illuminates the phantasm" is plainly and simply a metaphor, and any attempt to make sense of it is doomed to failure.

In a first attempt to save the analogy, Saint Thomas seeks to show that we can speak properly of "spiritual light." The topic is not of little importance. Among Scholastics, the reference to a spiritual and intellectual light is recurring. ${ }^{14}$ Aquinas tries to find a justification for this use of language by proposing that there are two ways to name something:

a) According to the first and strictest sense. In this way, "vision" means the sense of sight.

b) According to the common use of the name. In this way, for example, in everyday language "to see" is also used to designate other types of knowledge, because of the nobility of the sense of sight. In this case, the verb "to see" is used in a wider sense, as when we say "vide quommodo redolet"15, or "vide quommodo est calidum"16.

13 "O intelecto agente é, de algum modo, luz."

14 Saint Thomas discusses the spirituality of light in Summa Theologiae, q. 67: "(...) quaeruntur quatuor. Primo: utrum lux proprie in spiritualibus dici possit. Secundo: utrum lux corporalis sit corpus. Tertio: utrum sit qualitas. Quarto: utrum conveniens fuit prima die fieri lucem”. (“(...) busca-se a resposta a quatro [questões]. Primeiro: se a luz pode propriamente ser atribuída às coisas espirituais. Segundo: se a luz corporal é um corpo. Terceiro: se é uma qualidade. Quarto: se foi conveniente a luz ter sido feita no primeiro dia).

15 "Vê como exala cheiro".

16 "Vê como é quente". 
According to Saint Thomas, we can speak both ways about light. In a first sense, "light" is used to mean that principle which allows us to see; in a second sense, "light" is extended to mean any other form of knowledge. This way, an expression such as "God is light", if taken in the first sense, is nothing but a metaphor, while taken in the second it is properly used to mean something specific. ${ }^{17}$

This device allows Saint Thomas to use the word "light" to describe spiritual substances. He is not willing to say that it is a metaphor. However, although his distinction between the proper sense and the metaphorical sense is subtle, it does not seem to do the job. It seems to be enough if we see that when we say "videns quommodo sapit" 18 , we do to mean to use a metaphor, as when someone says "The sun is rising:" in neither case we mean to give to our expression a literal sense, and yet we are not using it as a metaphor, like in "He was quenched in the chaste beams of a watery moon." We are simply using everyday, common language, whose meaning is established by its use. It is a matter of pragmatic semantics. Saint Thomas is very clever in appealing to this strategy.

However, it is reasonable to doubt whether this distinction explains the ratio communis of the analogy: the use of an analogy does not excuse us from explaining the ratio communis. What does the light of spiritual substances have in common with the light of a candle? If we push this question to the limit, we should see that the well known analogy between light and the intellectus agens is imprecise, ambiguous and unexplanatory.

The metaphor of light is an improper analogy; it seems to turn the terms (A/B: C/D) upside down.

To complicate matters even further, we should observe that Aristotle's reasoning is different from ours thanks to modern physics. For us, light makes colors, or rather, colors are variations of electromagnetic radiation within the range of frequencies accessible to the human eye: what we usually call "light." For Aristotle, colors are visible in themselves, and Aquinas's commentary is deeply faithful to this idea. The distance between Aristotle's (and Aquinas') cosmology allows us to comfortably see the limits of the analogy of light/color::Intellectus Agens/phantasmata. I say "comfortably," because the distance allows us to see how Saint Thomas makes use of the similarity between Intellectus Agens and lux when it is convenient for him to do so, while he neglects it when it does not fit into other of his theories. Such

17 See Summa Theologiae, edited by Francisco Barbado and Santiago Ramírez (Madrid: B.A.C., 1969). I, q. 67 , a. 1.

18 "Vendo como sabe". 
is the "advantage" garnered by not specifying the ratio communis of an analogy. At this point we can see why De Anima II, 7 makes the analogy of light ambiguous. Analogies work because there is a ratio communis between the terms being compared: as we find more limitations in an analogy, we find it less convincing.

Before developing this argument any further, it is important to notice that Saint Thomas himself seems to regard the analogy of light as an example and not as an argument. So even if the simplicity of Aristotle's optics weakens the likeness between light and Intellectus Agens, and therefore hinders the construction of a valid argument, the real argument for the demonstration of the existence of the Intellectus Agens is to be found elsewhere, in the theory of act and potency:

[Aristotle] first shows by an argument and illustration that there is such a thing as the Intellectus Agens. (...) In any nature which alternates between potency and actuality we must posit a factor akin to the matter which, in any given class of things, is potentially all the particulars included in the class; and another factor which operates as an active and productive cause...

This argument has its own difficulties, for Aristotle — and Aquinas with him - explains this proportion by appealing to another analogy: the agent modifies the patient "... like art with respect to its material". ${ }^{19}$ This analogy is also vulnerable, but I will not discuss it in this paper.

\section{The light of the Intellectus Agens}

I might be accused of excessive harshness against the analogy of light. However, I regard my objections as justified, precisely because the analogy is very suggestive. The analogy of light enjoys an attractive, wealthy rhetorical power. It is fair, therefore, to show its limitations, the ratio or proportion between light/color : Intellectus Agens/phantasmata.

Summarizing the argument, Aquinas comes to say: What makes it therefore in act with respect to intelligible objects is the fact that it is an active immaterial force able to assimilate other things to itself, i.e., immaterialize them. In this way it renders actually intelligible something that was only potentially

19 In De Anima III, lectio X, (Rome: Marietti, 1959), § 728, Aristotle writes in De Anima 430a 10-14: "Since in every class of things, as in nature as a whole, we find two factors involved, a matter which is potentially all the particulars included in the class, a cause which is productive in the sense that it makes them all (the latter standing to the former, as e.g. an art to its material), these distinct elements must likewise be found within the soul." 
intelligible: like light, which without containing any particular color, brings colors into act. ${ }^{20}$

According to this argument, the ratio of the analogy seems to be:

a) Light and Intellectus Agens are causes, as both make a potential object $\mathrm{X}$ turn into an actual X.

b) Light and Intellectus Agens are actus.

There are difficulties both in (a) and in (b).

a) What type of cause is the Intellectus Agens?

The expression Intellectus Agens used by Aquinas suggests, unequivocally, an efficient cause. Saint Thomas himself calls it a vis activa, a power specific to the human soul. Thomas is not happy with the idea of conceiving the Intellectus Agens merely as a necessary condition for human knowledge. It is not an external agent, like the sun. According to him, the Intellectus Agens is a formal principle of the human soul.

The Intellectus Agens is an efficient cause of human knowledge, but at the same time, it is a formal property of the soul. The sun is an efficient cause of the process of generation and corruption in the sublunar world, but not a part of this world. Thomas seemed to believe that the human being possesses a series of powers or specific powers - intellect, will, memory... - as properties in virtue of its own soul; Aquinas calls these powers "faculties." For example, the human being has the capacity to have memories, while oysters lack this capacity. This is so because the human soul and the oyster soul have different formal specifications. The Scholastics developed this idea stating that the accident quality is divided into various subclasses. The habitus (e. gr., virtue) and the faculty (e. gr., the intellectus) are two subclasses of quality. Consequently, they described the Intellectus Agens as a quality of the human soul. As a consequence, if the Intellectus Agens is a faculty - a quality enabled by the human soul - it cannot be a separate substance. If the Intellectus Agens is a faculty of the human being, Latin Averroism is untenable. The human faculties are not substances but accidents and, therefore, the Intellectus Agens cannot be a separated substance.

If this is so, then the Intellectus Agens cannot be the formal cause of the human soul and - simultaneously - the efficient cause of the immateriality of the phantasmata and, quodammodo, the efficient cause of its own act. 
The Intellectus Agens, however, is different from other faculties for, unlike most faculties, it does not need a proper object to be actualized. Saint Thomas states it clearly: "[The Intellectus Agens] consists in its being essentially in act; whereas the Intellectus Possibilis is essentially potential and comes to act only by receiving an intelligible object". ${ }^{21}$

b) What it means to say that the intellect is an act?

If we are to use the analogy of light, then we have to say that the Intellectus Agens is a floodlight, a source of light that is never extinguished. It is not a twinkling light, small and intermittent, but an everlasting flame, always acting. Saint Thomas is specific: "sit in actu secundum suam substantiam," 22 as a form without matter.

Let's see an example. Sight is a power of the animal soul. However, a dog or cat does not exercise this power continually: a sleeping dog cannot see. On the contrary, it seems that, according to its nature, the Intellectus Agens is always active. We may object that the Intellectus Agens is always in act, and yet the human being is not "intellecting" continually. The constant activity of the Intellectus Agens raises many difficulties.

Saint Thomas tries to describe Aristotle's Intellectus Agens as follows:

[Aristotle] states four qualities or conditions of the Intellectus Agens: first, its separation from matter; second, its impassibility; third, its purity, by which he means that it is neither made up of bodily natures nor conjoined with a bodily organ. Now these three qualities are also found in the Intellectus Possibilis; but the fourth is proper to the Intellectus Agens, and consists in its being essentially in act. ${ }^{23}$

This description must be complemented with three more relevant characteristics of the Agens. If the Intellectus Agens is in actu secundum suam substantiam, then:

a) It cannot be perfected, as its substance has no potentiality which can be actualized or perfected.

b) It is not susceptible of habits, as habits perfect faculties. ${ }^{24}$

c) It does not have a proper object.

21 In De Anima. III, lectio X (Rome: Marietti, 1959), § 732. At this point Saint Thomas faithfully follows Aristotle, who writes: "Thought in this sense of it is separable, impassable, unmixed, since it is in its essential nature activity".

22 "Seja em ato conforme sua substância".

23 In De Anima III, lectio X (Rome: Marietti, 1959), § 732

24 E. gr., the virtue of justice perfects the acts of the will. 
The latter point marks the difference between the agens and the patiens. Every faculty has a proper object: the object of sight is color, of hearing, sound, and the objects of the Intellectus Possibilis are intelligibilia. What is the object of the Agens? If we say that it is the phantasmata, then we fall into a contradiction, for then the human soul would have both an intellectus in act and an intellectus in potency simultaneously with respect to the same object, namely, phantasmata. We could try to solve this problem by saying that the Intellectus Possibilis and the Intellectus Agens are really the same faculty, under different names, where the former is the potential phase of the latter. However, Saint Thomas explicitly denies this possibility, for "it would seem impossible that one and the same thing should be at once in act and in potency to the same object; and therefore that these two intellects should belong to the one substance of the soul". ${ }^{25}$

Saint Thomas's answer gives no room for doubt. The activity of the Agens is different from that of the Possibilis. ${ }^{26}$ This means that the Intellectus Agens lacks a proper object. This conclusion should not be surprising: the proper object of a faculty brings that faculty into perfection: it is the factor which allows a faculty to pass from its potential to its actual stage. The phantasmata are illuminated by the Agens, but they do not perfect the Agens: the Intellectus Agens is not affected by the phantasmata: whether it illuminates or not, the Agens remains exactly the same. Just as the unmoved mover neither gains nor loses anything if the stars strive for it. The Intellectus Agens is perpetually impassible.

\section{The Intellectus Agens and the separate substances}

Aristotle describes the Intellectus Agens as a power which is always actual yet - paradoxically — is possessed by a subject which is a mix of act and potency. Although the soul is "always" actual, that is, while there is a soul, there is a living being (a somewhat uninformative statement, since the soul is the principle of life), the human soul can be perfected; it can acquire virtues and vices. The Intellectus Agens, on the contrary, seems to be more perfect than the soul itself: it cannot acquire any new qualities, it can only be perfected per accidens. Like a candle illuminating a column of the Parthenon is no more

25 In De Anima III, lectio X (Rome: Marietti, 1959), § 737.

26 Quoted from In De Anima III, lectio X, (Rome: Marietti, 1959) § 738: "But there is really no difficulty in this if we understand aright how the Intellectus Possibilis is potential with respect to intelligible objects, and how the latter are potential with respect to the Intellectus Agens. In the former case the potentiality is that of the indefinite to the definite; for the Intellectus Possibilis is not, as such, endowed with any definite and particular sensible thing's nature. Yet only definite particular natures are, as such, intelligible -hence Aristotle's early comparison of the intellectual power's relation to intelligible objects with that of a sheet of paper to particular definite pictures. And from this point of view the Intellectus Agens is not in act." 
perfect than a candle illuminating a toilet, the perfection of the Agens does not depend on whether it illuminates some phantasmata or not, or which one it illuminates. The Intellectus Agens is always exercising its capacity to illuminate, even if there are no objects to be illuminated.

However, there is an essential difference between the candle and the Agens: there are such things as extinguished candles, while the Agens is in actu secundum suam substantiam ${ }^{27}$. The Intellectus Agens of Hamlet is as actual as that of Sancho Panza. This is truly a paradox, for the Intellectus Agens must indeed be then more perfect than the rational soul, which is supposed to be its bearer; thus, it seems to be even more perfect than the act of the human body.

The Agens then is similar to Aristotelian separate substances, heavenly bodies for instance, because even though the latter might be material, they are not subject to corruption. Their circular movement is perpetual and perfect. They are substances which cannot be perfected by the exercise of their activity, and they are in possession of their proper finality now. Their bodily movement is a praxis, for their circular movement (kinesis) is not properly speaking an imperfection. In being circular, the telos of the kinesis of the heavenly bodies is the kinesis itself. So the Intellectus Agens and the celestial substances are in continuing praxis, and this praxis does not add any perfection to them. Neither the heavenly bodies nor their movers are perfected by attaining any external "end". The Intellectus Agens is similar to the unmoved mover of Metaphysics XII, because both are continually exercising their activity.

This similarity brings Saint Thomas into a difficult spot. It is very strange that this alleged faculty of the soul is in fact more perfect than its subject. Latin Averroists detected this likeness between the Intellectus Agens and the divine substances in the commentaries of Alexander and Averroes, and this may be why Saint Thomas was forced to seek some device to include the separate substances in his own interpretation.

\section{The Intellectus Agens as participation}

Saint Thomas' way to introduce separate substances in his account is to appeal to participation: "This active force [of the Intellectus Agens] is a certain participation in the intellectual light of separate substances". ${ }^{28}$ St Thomas' recourse is especially enigmatic, as the mysterious illuminating activity of the Agens remains unexplained.

27 "em ato conforme sua substância".

28 In De Anima III, lectio X (Rome: Marietti, 1959), § 739. 
The perfection of the Agens needs an explanation other than the human soul, since human nature cannot explain a power which seems superior to it. Now, while the human being is a compound, and the human soul is perfectible, the Agens is pure praxis; in fact, it is so perfect that it is difficult to see how it can depend on a mover or a cause. We have Aristotle's "explanation" for the dependence of separate substances on the unmoved mover: separate substances are moved by the unmoved mover as the lover is moved by the beloved. (This "explanation," by the way, is another metaphor.) This way, separate substances imitate and are attracted by the unmoved mover.

The Intellectus Agens, however, at least as it is described in In De Anima III lectio X, is in act secundum suam substantiam ${ }^{29}$. Its activity has no need for an explanation, as secundum suam substantiam est in actu $^{30}$. The same way that it is needless to ask why fire is hot, it is absurd to ask why the Intellectus Agens is in act.

However, if the Intellectus Agens is similar to separate substances, insofar as they are continually in act, there is a certain potentiality in heavenly substances, since they are subject to local motion. The Intellectus Agens, on the contrary, is exempt from any kind of kinesis. Therefore, we should say that the Intellectus Agens is more akin to the noesis noeseos than to celestial bodies. Consequently, its bearer, the human soul, should also be like the first mover, eternal, horismos. To no avail Saint Thomas claims that the soul is incorruptible but not eternal:

And in line with what he said at the beginning of this book, the soul might be separable from the body if any of its activities were proper to itself, he now concludes that the soul's intellectual part alone is immortal and perpetual. This is what he has said in book II, namely that this 'kind' of soul was separable from others as the perpetual from the mortal - perpetual in the sense that it survives for ever, not in the sense that it always has existed; for as he shows in Book XII of the Metaphysics, form cannot exist before their matter. The soul, then (not all of it, but only its intellectual part) will survive its matter. ${ }^{31}$

Even though the solution is clever, there are not enough reasons to believe that perpetuum is not equivalent here to aeternum. If the Intellectus Agens is perpetually in act, there are no conclusive reasons to say that, at some time, it did not exist. At least there are no motives if we follow Physics VIII and Metaphysics XII ad litteram. If the Intellectus Agens is perpetually in act, it could have existed from all eternity.

29 "conforme sua substância".

30 "é em ato conforme sua substância".

31 In De Anima III, lectio X (Rome: Marietti, 1959), § 743. 
There are more mysteries to be solved, however. The Intellectus of Metaphysics XII has an object: it knows itself. The Agens, however, is only light, it does not know anything. It illuminates and likens the phantasmata to itself, but it does not know them. Aquinas acknowledges this problem as he writes: "The third property of intellect as in act, differentiating it from the Intellectus Possibilis and from intellect in habitual possessions of knowledge, is that it is always in act; simply is the act of understanding. In the other cases intellect is sometimes in potency." 32 The word intelligere should not fool us: the Agens does not understand like the possibilis. The Agens illuminates, i.e., it actualizes the species, ${ }^{33}$ but it lacks knowledge, consciousness, and reflection.

Saint Thomas thus acknowledges that there are many similarities between the Intellectus Agens and the separate substances: therefore, this vis intellectiva cannot be caused by the human soul, for then the effect would be more perfect than its cause. However, he cannot say that it is a separate substance. The talk of Intellectus Agens as "participated light" is a desperate attempt to fix the problem of the lack of proportionality between the faculty and its bearer. Saint Thomas finds himself in a very awkward position: he cannot accept that the Intellectus Agens exists separately, but he cannot deny that the human soul is endowed with such a tremendous power. The participation mentioned by Saint Thomas is a kind of "reinforcement" of the causality of the soul. This seems the only way to make sense of the introduction of the mysterious steppingstone of the supralunar world.

\section{The problems of participation}

Aquinas description of the Agens as "virtus activa quaedam participatio luminis intellectualis a substantiis separatis" creates two difficulties. The first one is strictly textual: Saint Thomas explains the Intellectus Agens by appealing to some substances which, until then, he did not mention at all. The second difficulty is more systematic: "participation" is an empty word in Aristotelian philosophy.

The first difficulty is quite serious. In In De An. III, lectio X, n. 736, Saint Thomas appeals to separate substances, but in lectio XII of the same book, he states:

32 In De Anima III, lectio X (Rome: Marietti, 1959), § 741.

33 See In De Anima III, lectio X (Rome: Marietti, 1959), § 739. 
Whether, that is, our intellect, though conjoined with spatial magnitude (i.e., the body), can understand "anything separated" i.e., any substances separated from matter. He undertakes to pursue this enquiry later, not at present, because it is not yet evident that any such substances exist nor, if they do, what sort of thing they are. It is a problem for metaphysics. In fact, we don't know Aristotle's solution of this problem, for we have not the whole of his Metaphysics; either because it is not yet all translated, or possibly because he died before he could complete it. ${ }^{34}$

The contradiction between lectio X and XII is not solved by claiming that the latter is a spurious addition. There are parallel passages which support that he regarded Metaphysics Lambda as insufficient. ${ }^{35}$ Here Aquinas follows Saint Albert, who assumed the existence of a lost Aristotelian Metaphysics.

In lectio XII we can see the failure of Saint Thomas's tour de force. In lectio X, he notices that the Intellectus Agens is unexplainable without reference to the supralunar world. However, he is not satisfied with the metaphysics of book Lambda. Choosing not to discredit Aristotle, Saint Thomas is forced to conjecture that some material was missing.

The second difficulty concerning participation is of a theoretical nature. It is obvious that Aristotle had problems with the notion of participation. When Saint Thomas says that the Intellectus Agens is quaedam participatio luminis intellectualis a substantiis separatis he is clearly introducing a Platonic element into his own explanation, a recourse criticized by Aristotle in Metaphysics I, due to the emptiness of the term 'participation.' Aristotle's objections are particularly convincing.

What does 'participation' mean? In particular, what does participatio luminis a substantiis separatiis mean? Aristotle's objection to the Platonists is that the relationship of participation does not explain the world. "X participates in $Y$ " means nothing in ontological terms, save when it is assumed within the doctrine of the causes. This objection is equally applicable to the quaedam participatio luminis intellectualis a substantiis separatis. In Metaphysics XII and Physics VIII, the relationship between the sublunar world and God is not

34 In De Anima III, lectio XII (Rome: Marietti, 1959), § 785.

35 In Q. de anima, a. 16 c, Aquinas writes: "Hanc questionem [utrum anima coniuncta corpori possit intelligere substantias separatas] Aristoteles promisit se determinaturum in De Anima III, licet non inveniatur determinata ab ipso in libris eius qui ad nos pervenerunt" ("Aristóteles prometeu, ele próprio, haver de determinar essa questão em De Anima III [se a alma ligada ao corpo pode ser entendida como substâncias separadas], a qual não foi determinada em seus livros que chegaram até nós"); In De unitate intellectus, cap. 5. he also transcribes: "Quomodo autem Aristotiles hoc solveret, a nobis sciri non potest, quia illam partem Metaphicisice non habemus quam fecit de substantiis separatis (...)" ("Não pode ser conhecido por nós, contudo, de que modo Aristóteles resolveu isso, pois não temos aquela parte da Metafísica que ele escreveu a respeito das substâncias separadas (...)") other references can be found at De unitate intellectus, cap.1. See ALARCÓN, Enrique. Tomás de Aquino y la metafísica perdida de Aristóteles. Anuario Filosófico 33, Navarra, Universidad de Navarra, p. 557-571, 2000. 
explained in such an ambiguous word as "participation": God moves the world as the loved moves the lover; the separate substances imitate the perfection of God. The world moves toward "God," while the unmoved mover remains indifferent to this striving. "Living beings depend on the sun" is a proposition which makes sense. Also makes senses Saint Thomas' attribution of specific functions to different planets within the sublunar world. ${ }^{36}$ So how can we explain what the participation of the Intellectus Agens is?

That the human being should depend on an external agent - e.gr., the sun in order to exercise some proper activity, like seeing, does not make a big problem. There could also exist an efficient relationship between the heavenly motions and the sublunar bodies. Less clear is the relationship between the Unmoved Mover and the Universe, but the relationship loved-lover is concrete, and sufficiently explanatory. The real problem then is the ambiguity of the word "participation." Separate substances are causes of the Intellectus Agens according to the causal relationship of "participation". This relationship was discredited by Aristotle as meaningless; in evaluating this alleged causal relationship of participation, he concluded that it was not even a worthy metaphor.

Moreover, and perhaps more dangerously, it is surprising to find that the human being needs the light of separate substances in order to exercise its proper activity: intelligere. Throughout lectio VII and X Thomas argues that the Intellectus possibilis and Agens are natural principles of the individual human being. If these intellectus are not proper to each human being - Aquinas said - then the human being does not know. There must be some relationship between the intellectus and the human being, so that "ut sic eius intelligere sit nostrum intelligere". ${ }^{37}$ But with this recourse to participation we come across a paradox: the Agens is quaedam participatio of the vis intellectiva of the separate substances (eius intelligere), but it is nostrum intelligere, nonetheless. Did Aquinas forget the CNA?

When Saint Thomas appeals to separate substances, he was probably thinking on De generatione animalium I. He could not leave the matter in the hands of the Averroists. Aquinas sees that the Intellectus Agens is "too divine," too perfect to be merely human. The compound body-soul is not enough to sustain, so to speak, an intellectus in perfect praxis. This perfection is reserved for the Perfect Act of Metaphysics XII. Hence he had to appeal to an external

36 Aquinas believed that stars do influence, in a decisive way, the physical aspects of the sublunar world, including human behaviour. See In De Anima III, lectio IV (Rome: Marietti, 1959), § 621.

37 "Para que, assim, nosso compreender seja o compreender dele." In De Anima III, lectio V (Rome: Marietti, 1959), § 641. 
instance which "lends" its powers to the soul. The separate substances are the crutches of the intellectual activity of the human being. But in doing so, Aquinas seemed to forget his own argument against the Averroist claim that the intellect is not truly ours. Instead of turning the power of the Intellectus Agens into an idol, Saint Thomas chooses to make it dependent on the vis illuminativa of the separate substances. The CNA, which he had maintained against Averroism, has now turned against himself, as he introduced participatio. ${ }^{38}$ Participation guarantees the finitude of the Intellectus Agens and, at the same time, it allows us to attribute the intelligere to the concrete human being. This way, the condemnation of Tempier is avoided; at least in Saint Thomas' view. But the Thomist solution reminds us of Marinus, ${ }^{39}$ who also linked the heavenly bodies with the intellectual process. The Neoplatonic influence is clear. It is strange that Saint Thomas did not acknowledge it explicitly.

\section{Conclusion}

Why appeal to separate substances and not to God? Saint Thomas knows the illuminism of Augustinian stock. God illuminates the human intellect, he lends its quodammodo totis vis illuminativa. The Intellectus Agens might simply be God's illuminating the human soul. But Aquinas does not explain De Anima III, 5 this way. Saint Thomas's position seems terribly complicated when we have Augustine at hand.

Aquinas seems to prefer an uneconomical solution which involves the supralunar paraphernalia and the problem of participation. Ultimately, the stars and the separate substances depend on God too. Why, then, appeal to an intermediary power between the omnipotence of God and the activity of the Intellectus Agens?

I have shown that the reference to light creates many difficulties and, above all, that lectio $\mathrm{X}$ is not faithful to Aristotle. The analogy of light is elusive, and puts some limits on the well-known analogy lux / intellectus. Comparing the Intellectus Agens with a perfect light makes it difficult to explain how this divine power can dwell in the human soul (it looks a lot like the ghost

38 LOHR, C.H. The medieval interpretation of Aristotle. In: KRETZMANN, Norman; KENNY, Anthony; JAN, Pinborg (Ed.). The Cambridge History of Later Medieval Philosophy. Cambridge: University Press, 1997.

39 BLUMENTHAL, Henry J. Neoplatonic elements in De Anima commentaries. In: SORABJI, Richard (Ed.). Aristotle Transformed. London: Duckworth., 1990. p. 305-324: "Marinus, we are told, held that the active intellect was not that which is principle of all things, but some demonic or angelic intellect. At first sight this might suggest medieval interpretations rather than De Anima. Once again what we have is straight Neoplatonism. Marinus too is working with a series of highly, not to say excessively, differentiated entities: the angelic intellect is neither ours, nor that of the principle of all things". 
in the machine). Finally, the participatio luminis a substantiis separatii is an expression which lacks explanatory power.

Prima facie, Aquinas is very Aristotelian in his commentary to De Anima II, 5. The explanans of the intellectual function of the human being must inhere in the very same human being. To put the explanans of intellectual knowledge outside of the human being is to commit the error imputed to the Platonists. For Aristotle, as commented by Aquinas, the formal cause of Rocinante must be in the whole, a singular animal. The separated horse does not explain the existence of Rocinante. Saint Thomas knows that intelligere is an act which is naturally attributed to the human being. Its cause must be, therefore, the substantial form: an ontological principle which is always internal to the agent. Based on this argument, Saint Thomas launches his offensive against Alexander, Averroes, Avicenna and Siger. The heart of the Thomistic argument - which I called the CNA — is that natural operations depend on formal principles.

However, in announcing the CNAAquinas forgets that in order to exercise natural acts (or activities), we cannot rule out the intervention of external efficient causes, like an aid to natural motion. Only God is autarchic. To make the CNA work, Saint Thomas has to reject the "externality" of the Agens.

Subsequently, however, Aquinas weakens the CNA to accommodate his own appeal to participation on the separate substances. Aquinas betrays his own intentions by accepting that the exercise of the human intelligere requires the intervention of separate substances. When he realizes that this concession makes him closer to Latin Averroism, Aquinas introduces the idea of participation. The betrayal of Aristotle is, at this point, full and frontal.

Why did Thomas do this?

The only reason I can think of is that he was trying to achieve the goal of his commentary: to guide young students. I fear that the most important factor for Saint Thomas' decision was not to explain Aristotle's De Anima III, 5, but to explain it in such a way as to make it compatible with the Catholic creed, at the expense of an appeal to the doctrine of participation.

Saint Thomas did not recognize the validity of Augustinian illuminism at the University of Paris. Such a position was agreeable with orthodoxy, but it was neither popular nor attractive. If he were to follow Augustine, he would have dismissed Aristotelianism altogether, to the dismay of his students. Experience had shown that the condemnations of Aristotelian philosophy were not effective. Students kept reading it, and authority was eroded. Thus, it seemed more important for Aquinas to guide, rather than to condemn. A compromise with Aristotle's admirers seemed better than a full standoff. 
In short, Saint Thomas may have subordinated the text and his interpretation to a hidden pastoral agenda. He could not openly refute Aristotle for strategic reasons, but he could not exclude the clause of participatio either, also for doctrinal reasons.

Probably this ambiguity was detected when Saint Thomas was condemned. Obviously, Aquinas was not an Averroist such as Siger, but his commentary to De Anima III, 5 is at least suspicious. It looks like a desperate attempt to save Aristotle from his paganism.

There might, perhaps, be an objection to my conclusion. Why Saint Thomas did not leave the Intellecus Agens out of his theological works? The explanation is the same. Saint Thomas was clever. He knew that Aristotle had come to stay. It was necessary to assimilate the science of this pagan into the Catholic world as soon as possible. Otherwise, it was to become a source of pandemic heresy. If the price for "baptizing" Aristotelian philosophy was the betrayal of Aristotle, by appealing to participatio for instance, it was perhaps well worthwhile. The history of Aristotelianism shows us how efficient Saint Thomas' strategy was. It took the West a long time to take of the scholastic glasses through which they read Aristotle.

Of course, not all can be reduced to pastoral strategy. Saint Thomas knew well that many concepts of the corpus Aristotelicum were of great use to Latin theology, but how he achieved this goal is another matter.

Tradução do latim: Daniel Peluci Carrara 